\title{
Perfil de Sensibilidade das Cepas Escherichia coli Isoladas de Carcaças de Frangos Congelados Comercializados no Distrito Federal
}

\author{
Luana Lôbo Queiroz (I), Thaís Silva Alves (I), Juliana Camargos \\ Oliveira Peres (I)
}

(I) UCB - Universidade Católica de Brasília (Campus I - QS 07 Lote 01 EPCT, Águas Claras CEP: 71966-700 - Taguatinga/DF)

\section{Resumo}

Entre as bactérias gram negativas, anaeróbias facultativas que compõem a família Enterobacteriaceae está a Escherichia coli. A infecção por E.coli (colibacilose) representa um sério problema na avicultura. É responsável por grande parte das perdas nos criadouros, gerando assim, perdas econômicas significativas. Na produção de frangos de corte, é constante o uso de antimicrobianos para prevenir ou tratar as lesões causadas pela E.coli, visando à diminuição da mortalidade relacionada com a colibacilose. O uso irracional dos agentes antimicrobianos através de doses com concentrações subterapêuticas, tempo prolongado e de forma inadequada, faz com que haja uma pressão na seleção de genes de resistência antimicrobiana, contribuindo assim com o aparecimento de bactérias mutirresistentes. As amostras utilizadas neste trabalho foram obtidas a partir das análises de controle de qualidade prestadas a indústrias do Distrito Federal pelo Laboratório de Microbiologia e Higiene dos Alimentos da Universidade Católica de Brasília. Inicialmente foi realizada a etapa de isolamento e identificação das bactérias, utilizando meios de crescimento para enriquecimento e meios seletivos, além de provas bioquímicas. Em seguida procedeu-se a realização dos antibiogramas pelo método de disco difusão testando os seguintes antibióticos: eritromicina, cefoxitina, meropenem, cefalexina, gentamicina, cefotaxima, bacitracina, amoxicilina/ácido clavulânico, ciprofloxacina, imipenem e sulfazotrim.

\footnotetext{
Referência:

Luana Lôbo Queiroz, Thaís Silva Alves, Juliana Camargos Oliveira Peres. Perfil de Sensibilidade das Cepas Escherichia coli Isoladas de Carcaças de Frangos Congelados Comercializados no Distrito Federal. In: Anais do 12을 Congresso Latinoamericano de Microbiologia e Higiene de Alimentos - MICROAL 2014 [= Blucher Food Science Proceedings, num.1, vol.1]. São Paulo: Editora Blucher, 2014. DOI 10.5151/foodsci-microal-322
} 
Após incubação as cepas foram classificadas como resistentes, intermediárias ou sensíveis aos antibióticos testados. Até o presente momento 16 amostras foram analisadas, 2 amostras são resistentes à gentamicina, cefotaxima e sulfazotrim; 2 amostras apresentaram resistência somente a sulfazotrim; uma a cefotaxima, sulfazotrim e ciprofloxacina; 2 tiveram resposta intermediária a cefotaxima. Todas as amostras são resistentes à bacitracina. Por meio das análises foi possível observar que entre as cepas testadas, parte delas já apresenta resistência a antibióticos de classes diferentes, e em alguns casos a mais de um tipo de antibiótico. A pesquisa segue em curso e visa analisar 50 amostras ao total.

Palavras-Chave: Escherichia coli, Avicultura, Antibióticos, Resistência Agência de Fomento: 